\title{
Implications of Sulfur Speciation on the Assessment of Acid Rock Drainage Generating Potential: A Study of South African Coal Processing Wastes
}

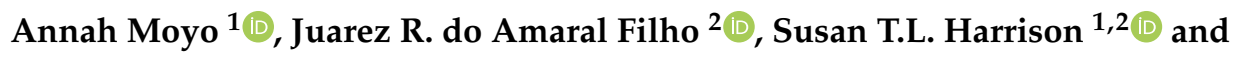 \\ Jennifer L. Broadhurst ${ }^{1, *}$ \\ 1 Minerals to Metals Initiative, Department of Chemical Engineering, University of Cape Town, Rondebosch, \\ Cape Town 7700, South Africa; ann3mo@gmail.com (A.M.); sue.harrison@uct.ac.za (S.T.L.H.) \\ 2 Centre for Bioprocess Engineering Research, Department of Chemical Engineering, University of Cape Town, \\ Rondebosch, Cape Town 7700, South Africa; juarez.amaralfilho@uct.ac.za \\ * Correspondence: jennifer.broadhurst@uct.ac.za
}

Received: 22 October 2019; Accepted: 9 December 2019; Published: 12 December 2019

check for updates

\begin{abstract}
The presence of sulfur in coal processing wastes can lead to environmental impacts, such as acid rock drainage (ARD). However, not all sulfur species are acid-forming, and the implications of sulfur speciation when assessing acid rock drainage potential by means of static chemical tests are not well understood. This study set out to evaluate the implications of different sulfur forms on the assessment of acid rock drainage potential using static laboratory-scale tests and to investigate the reliability of methods for the analysis of such forms for the case of three South African coal processing wastes. Both the International Organization for Standardization (ISO) 157:1996 and Australian Coal Association Research Program (ACARP) C15034 protocols were found to be suitable tools for analyzing the different forms of sulfur. Acid-generating sulfur forms constituted between $53 \%$ and $64 \%$ of the total sulfur in the wastes evaluated, with the maximum potential acidity (MPA) and net acid-producing potential (NAPP) values calculated on the basis of acid-forming sulfur being significantly lower than those calculated on the basis of total sulfur content. Results also showed that the partial conversion of sulfur species under the relatively aggressive conditions of the acid-neutralizing capacity (ANC) and net acid generation (NAG) tests may overestimate the potential acid generating potential in the case of coal. These findings highlight the uncertainties associated with standard ARD static tests and the importance of taking sulfur speciation into account when calculating the MPA for coal processing wastes.
\end{abstract}

Keywords: sulfur forms; coal processing wastes; acid rock generating potential; acid-base accounting; net acid generation

\section{Introduction}

The presence of sulfur-bearing phases, particularly pyrite, in coal and coal wastes leads to environmental impacts such as acid rock drainage (ARD) upon oxidation of the sulfur in the presence of moisture and oxygen [1-3]. Although the composition of South African (SA) coal differs across seams and across the 19 coalfields, in general, the SA coals are high in ash (typically 20-40\%) and low in sulfur (typically between $0.15-1.8 \%$, although values as high as $15 \%$ have been recorded) [4]. As a result of the high extraneous mineral matter and moisture content, the run-of-mine (ROM) coal has low calorific values. Thus the coal has to be beneficiated to lower the ash (to below $15 \%$ and $21 \%$ for export and local thermal coals, respectively) and sulfur (to below $1 \%$ for both local and export thermal coals) contents, and to increase calorific value (to above 27.5 and $24.7 \mathrm{MJ} / \mathrm{kg}$ for export and local thermal coals, respectively) [5,6]. 
The coal preparation process to produce clean coal usually involves two major operations, namely screening and beneficiation (generally termed washing). The screened material can be sold directly or processed further by washing or beneficiation if the screening alone does not meet the required product specifications [7]. A typical South African washing plant employs dense medium separation (DMS) to beneficiate coarse $(>25 \mathrm{~mm}$ ) and intermediate/middling $(1-25 \mathrm{~mm})$ coal, whilst spiral concentrators are commonly used for beneficiation of fine $(0.15-1 \mathrm{~mm})$ coal [8]. Whilst some plants beneficiate ultra-fine $(<0.15 \mathrm{~mm})$ coal by means of froth flotation, many South African collieries still dispose of ultra-fines directly after dewatering. Historically, dewatering was mainly by means of thickeners, but many collieries have now installed more sophisticated dewatering equipment, such as filter presses to improve water recovery, reducing the moisture content of the slurry to roughly $25 \%$ [8]. Although the term "discards" is sometimes used in reference to all wastes arising from the coal preparation process, two types of coal processing wastes can be differentiated: discard waste from the processing of coarse, intermediate and fine coals, and ultra-fine slurry or slurry tailings [8-10]. Discards are compacted and piled into dumps which are then covered with soil and plant vegetation, whilst ultra-fine coal slurry wastes are either used as backfill material or disposed of, either in slurry dams or together with discards in the dumps [8]. Total processing waste typically accounts for between $20 \%$ and $22 \%$ of the ROM coal, $4-6 \%$ of which is in the form of an ultra-fine slurry. The typical composition of the coal wastes according to the national inventory of 2001 by the Department of Minerals and Energy (DME) is presented in Table 1.

Table 1. Typical compositions of discard and ultra-fine slurry coal waste, as adapted from the SA department of minerals and energy [9].

\begin{tabular}{lcc}
\hline \multicolumn{1}{c}{ Parameter } & Discards & Ultra-Fine Slurry \\
\hline Ash $(\%)$ & $30-60$ & $10-50$ \\
Caloric value (MJ/kg) & $11-20$ & $20-27$ \\
Fixed carbon $(\%)$ & $18-42$ & $41-56$ \\
Sulfur (\%) & $1-5$ & $\leq 2$ \\
Volatile matter $(\%)$ & $18-24$ & $17-27$ \\
\hline
\end{tabular}

\subsection{The Occurrence of Sulfur in Coal and Coal Processing Wastes}

Sulfur occurs in coal in three main forms: organically bound sulfur (usually $<3 \%$ ), inorganic sulfides and inorganic sulfates (rarely exceed $0.1 \%$ except in weathered coal samples). Sulfur in coal rarely occurs as free sulfur, which is usually produced during coal weathering [11-13]. Whilst the main inorganic sulfide sulfur occurs mainly in the form of pyrite $\left(\mathrm{FeS}_{2}\right)$, other sulfides such as galena $(\mathrm{PbS})$, sphalerite $(\mathrm{ZnS})$, arsenopyrite $(\mathrm{FeAsS})$, and chalcopyrite $\left(\mathrm{CuFeS}_{2}\right)$ may occur in coal in trace amounts [11]. Organic sulfur compounds are generally grouped into thiophenes, mercaptans, disulfides and aliphatic and aryl sulfides [13]. The pyritic and organic sulfur in South African coal increases with increasing vitrinite content from west to east geologically [4]. The organic sulfur occurs embedded in the coal matrix during the formation period and is therefore hard to remove during washing, while the inorganic sulfur occurs along the cleats and cracks and is more easily removed by washing. Coal beneficiation wastes, particularly discards, thus tend to have higher inorganic sulfur/organic sulfur ratios than the ROM coal, with the absolute values depending on the coal petrography and subsequent preparation processes employed [13]. Reported values for sulfur and sulfur forms in ultra-fine slurry wastes from South African coalfields are presented in Table 2. 
Table 2. Total sulfur and sulfur forms in South African ultrafine coal wastes from collieries in Waterberg, Witbank [14] and Middleburg [15,16].

\begin{tabular}{cccc}
\hline \multirow{2}{*}{ Sulfur Form } & \multicolumn{3}{c}{ Content (Mass \% of Whole Coal) } \\
\cline { 2 - 4 } & Waterberg & Witbank & Middleburg \\
\hline Total sulfur & 2.04 & 4.18 & $0.80-1.10$ \\
Sulfide sulfur & 0.98 & 2.58 & $0.64-1.05$ \\
Organic sulfur & 0.56 & 0.16 & $0.25-0.51$ \\
Sulfate sulfur & 0.50 & 1.44 & $0.05-0.50$ \\
\hline
\end{tabular}

\subsection{Sulfur Speciation and ARD Formation}

Previous studies have shown that the environmental risks associated with coal preparation and utilization can be attributed largely to the presence of sulfur and its speciation [16-18]. A key environmental risk is that of ARD generation, which has been mainly attributed to the presence of pyrite in coal seams and coal waste piles [17-20]. The mechanisms of the formation of ARD is documented by several researchers such as $[1,21-25]$. In ARD formation, pyrite $\left(\mathrm{FeS}_{2}\right)$ oxidizes in the presence of water to ferrous ions $\left(\mathrm{Fe}^{2+}\right)$, acidic ion $\left(\mathrm{H}^{+}\right)$and sulfates $\left(\mathrm{SO}_{4}{ }^{2-}\right)$ as shown in Equation (1). The ferrous iron is subsequently oxidized to ferric iron $\left(\mathrm{Fe}^{3+}\right.$ ) (Equation (2)). At $\mathrm{pH}$ values below 4.5, ferric iron becomes the dominant oxidant, oxidising pyrite according to the reaction shown in Equation (3) [26]. In natural disposal systems, the ARD reactions are catalysed by acidophiles such as Acidothiobacillus ferrooxidans (Fe and S oxidizer), Acidothiobacillus thiooxidans (S oxidizer) and Leptospirillum ferrooxidans (Fe oxidizer) [25]. The cyclic oxidation of pyrite and generation of ferric ions can continue for decades producing more acid and sulfates which can contaminate water bodies if not contained.

$$
\begin{gathered}
\mathrm{FeS}_{2}+\frac{7}{2} \mathrm{O}_{2}+\mathrm{H}_{2} \mathrm{O} \rightarrow \mathrm{Fe}^{2+}+2 \mathrm{SO}_{4}{ }^{2-}+2 \mathrm{H}^{+} \\
\mathrm{Fe}^{2+}+\frac{1}{4} \mathrm{O}_{2}+\mathrm{H}^{+} \rightarrow \mathrm{Fe}^{3+}+\frac{1}{2} \mathrm{H}_{2} \mathrm{O} \\
\mathrm{FeS}_{2}+14 \mathrm{Fe}^{3+}+8 \mathrm{H}_{2} \mathrm{O} \rightarrow 15 \mathrm{Fe}^{2+}+2 \mathrm{SO}_{4}{ }^{2-}+16 \mathrm{H}^{+}
\end{gathered}
$$

Although pyrite is the acid-producing sulfide with the highest capacity in mine wastes, other sulfides such as pyrrhotite, arsenopyrite, chalcopyrite, galena and sphalerite (reported to also occur in coal [11] are also acid-producing (as shown in Equations (6)-(10)) but with a low capacity $[27,28]$. Reactivity is in the order pyrrhotite $>$ galena-sphalerite $>$ pyrite-arsenopyrite $>$ chalcopyrite if galvanic and biological interactions are not considered [29-31].

$$
\begin{gathered}
\mathrm{Fe}_{(1-x)} \mathrm{S}+\left(\frac{2-x}{2}\right) \mathrm{O}_{2}+x \mathrm{H}_{2} \mathrm{O} \rightarrow(1-x) \mathrm{Fe}^{2+}+\mathrm{SO}_{4}{ }^{2-}+2 x \mathrm{H}^{+}, \\
\mathrm{FeAsS}+\frac{7}{2} \mathrm{O}_{2}+6 \mathrm{H}_{2} \mathrm{O} \rightarrow \mathrm{Fe}(\mathrm{OH})_{3}+\mathrm{SO}_{4}{ }^{2-}+\mathrm{H}_{2} \mathrm{AsO}_{4}^{-}+3 \mathrm{H}^{+}, \\
2 \mathrm{CuFeS}_{2}+\frac{17}{2} \mathrm{O}_{2}+5 \mathrm{H}_{2} \mathrm{O} \rightarrow 2 \mathrm{Cu}^{2+}+2 \mathrm{Fe}(\mathrm{OH})_{3}+4 \mathrm{SO}_{4}{ }^{2-}+4 \mathrm{H}^{+}, \\
\mathrm{ZnS}+2 \mathrm{O}_{2} \rightarrow \mathrm{Zn}^{2+}+\mathrm{SO}_{4}{ }^{2-}, \\
\mathrm{PbS}+2 \mathrm{O}_{2} \rightarrow \mathrm{Pb}^{2+}+\mathrm{SO}_{4}{ }^{2-} .
\end{gathered}
$$

Additional acid is generated through the formation of secondary precipitates. At $\mathrm{pH}$ values above 3 , the hydrolysis of ferric iron, $\mathrm{Fe}^{3+}$, forms hydroxide precipitates, generating acidity in accordance with the reactions in Equations (9) and (10) [25,32]. At lower $\mathrm{pH}$ values the formation of secondary acid-forming sulfates, such as jarosite (Equation (11)) occurs, generating further acid. 


$$
\begin{gathered}
\mathrm{Fe}^{3+}+3 \mathrm{H}_{2} \mathrm{O} \rightarrow \mathrm{Fe}(\mathrm{OH})_{3}+3 \mathrm{H}^{+}, \\
\mathrm{Fe}^{3+}+2 \mathrm{H}_{2} \mathrm{O} \rightarrow \mathrm{FeOOH}+3 \mathrm{H}^{+}, \\
3 \mathrm{Fe}^{3+}+\mathrm{K}+2 \mathrm{SO}_{4}{ }^{2-}+6 \mathrm{H}_{2} \mathrm{O} \leftrightarrow \mathrm{KFe}_{3}\left(\mathrm{SO}_{4}\right)_{2}(\mathrm{OH})_{6}+6 \mathrm{H}^{+} .
\end{gathered}
$$

Other secondary acid-forming sulfates reported to occur in weathered coal and coal wastes include alunite $\left(\mathrm{KAl}_{3}\left(\mathrm{SO}_{4}\right)_{2}(\mathrm{OH})_{6}\right)$, melanterite $\left(\mathrm{FeSO}_{4} \cdot 7 \mathrm{H}_{2} \mathrm{O}\right)$ and schwertmannite $\left(\mathrm{Fe}_{8} \mathrm{O}_{8}(\mathrm{OH})_{6}\left(\mathrm{SO}_{4}\right) \cdot \mathrm{nH}_{2} \mathrm{O}\right)$. These metastable sulfur species generate acid when they convert to more stable ferric hydroxides and oxides as shown in Equations (12) and (13) for jarosite and melanterite respectively [33,34]:

$$
\begin{gathered}
\text { jarosite } \rightarrow \text { geothite }: \mathrm{KFe}_{3}\left(\mathrm{SO}_{4}\right)_{2}(\mathrm{OH})_{6}+3 \mathrm{H}_{2} \mathrm{O} \rightarrow 3 \mathrm{Fe}(\mathrm{OH})_{3}+\mathrm{K}^{+}+3 \mathrm{H}^{+} 2 \mathrm{SO}_{4}{ }^{2-}, \\
\qquad \mathrm{FeSO}_{4} \cdot 7 \mathrm{H}_{2} \mathrm{O}+\frac{1}{4} \mathrm{O}_{2} \rightarrow \mathrm{Fe}(\mathrm{OH})_{3}+\frac{9}{2} \mathrm{H}_{2} \mathrm{O}+2 \mathrm{H}^{+}+\mathrm{SO}_{4}{ }^{2-}
\end{gathered}
$$

However, sulfates of the alkaline earth metals gypsum $\left(\mathrm{CaSO}_{4} \cdot 7 \mathrm{H}_{2} \mathrm{O}\right)$ and epsomite $\left(\mathrm{MgSO}_{4} \cdot 7 \mathrm{H}_{2} \mathrm{O}\right)$, commonly found in coal and coal wastes, are non-acid forming [33]. The organic sulfur in coal is presumed to be non-acid forming as it is mainly present in the form of heterocyclic compounds organically bonded to the coal $[33,35]$.

The acid produced from the pyrite and other acid-forming sulfur species is neutralized by gangue material such as carbonates, silicates and clay minerals. The neutralizing potential of these minerals varies according to their reaction rates and is dependent on the environmental $\mathrm{pH}$ [22]. The carbonate with the highest neutralizing potential is calcite $\left(\mathrm{CaCO}_{3}\right)$, as it displays the most rapid dissolution. Other effective neutralizing carbonates are magnesite $\left(\mathrm{MgCO}_{3}\right)$, dolomite $\left(\mathrm{CaMg}\left(\mathrm{CO}_{3}\right)_{2}\right)$ and ankerite $\left(\mathrm{CaFe}\left(\mathrm{CO}_{3}\right)_{2}\right)$ [22]. Many of the silicate minerals, particularly quartz $\left(\mathrm{SiO}_{2}\right)$, are inert but others, such as forsterite $\left(\mathrm{Mg}_{2} \mathrm{SiO}_{4}\right)$, olivine $\left(\mathrm{Mg}_{1.6} \mathrm{Fe}^{2+}{ }_{0.4} \mathrm{SiO}_{4}\right)$, wollastonite $\left(\mathrm{CaSiO}_{3}\right)$ and serpentine $\left(\mathrm{Mg}_{2.25} \mathrm{Fe}^{2+}{ }_{0.75} \mathrm{Si}_{2} \mathrm{O}_{5}(\mathrm{OH})_{4}\right)$ are acid neutralizing, although they have slower dissolution rates and lower neutralizing capacities compared to carbonates $[27,28]$. The silicates can maintain neutral conditions if the acid formation rate is slow [22]. The net acid generation potential is, therefore, a function of both the acid-forming and neutralizing capacity, as well as the relative rates of reaction of the constituent minerals of a sample $[27,28]$.

\subsection{Assessment of Acid Rock Drainage Potential}

Due to their relatively low cost and rapid turn-around times, laboratory-scale static geochemical tests are commonly used to assess the potential for mineral-bearing solids to generate ARD. Among these, acid-base accounting (ABA) and net acid generation (NAG) tests are widely applied $[25,36]$. In the ABA method, the net acid-producing potential (NAPP) is calculated as the difference between maximum potential acidity (MPA) and acid-neutralizing potential (ANC). The MPA is usually determined by multiplying the total sulfur content (\%) by the stoichiometric factor of 30.6 giving a result in $\mathrm{kg}$ $\mathrm{H}_{2} \mathrm{SO}_{4} / \mathrm{t}$ [36]. However, researchers have reported that estimating MPA based on total sulfur may misclassify the test samples because not all the sulfur is present as pyritic sulfur [33,34]. This is particularly the case for coal and coal wastes, which contain sulfur in the form of non-acid generating organic sulfur and sulfates. Using total sulfur to calculate MPA thus overestimates the NAPP, prompting researchers to recommend that MPA calculations be based on pyritic sulfur, rather than total sulfur, content [33-35].

The ANC is determined empirically by reacting the solid with a known amount of $\mathrm{HCl}$ and back-titrating the excess acid with a standard solution of $\mathrm{NaOH}$. In conducting the ANC tests, it is assumed only acid-neutralizing minerals react with the added $\mathrm{HCl}$ and the sulfur species will remain unchanged. However, due to the lack of selectivity, some acid-soluble sulfides or sulfates can be partially oxidized or solubilized [37,38], thus potentially under-estimating the ANC of a sample. Although a number of versions of the ANC method exist, each with slight modifications to the 
method $[34,36,39,40]$, most of these aim to determine the neutralizing capacity associated with the reactive carbonate minerals (such as calcite, dolomite) and fast weathering silicates (such as anorthite, olivine and wollastonite). However, many researchers have reported that the relatively aggressive conditions of the ANC tests overestimate the neutralizing capacity by promoting the dissolution of silicates that are slow reacting or even completely inert under environmental conditions [27,28,41,42].

In NAG tests the sample is dissolved in a known quantity of hydrogen peroxide $\left(\mathrm{H}_{2} \mathrm{O}_{2}\right)$ as an oxidant, to allow for both the oxidative dissolution of acid-generating forming minerals and dissolution of acid-neutralizing minerals, before back titrating the excess acid with a standard solution of $\mathrm{NaOH}$. This test assumes that all the sulfide sulfur is converted into soluble sulfate while all the acid-neutralizing components simultaneously buffer the acid produced. The NAG $\mathrm{pH}$ and the NAG capacity at $\mathrm{pH} 4.5$ and $\mathrm{pH} 7$ give an indication of the net acid-generating capacity. Misleading results have been reported for samples containing high pyritic sulfur $(>0.7-1 \%)$, as the $\mathrm{H}_{2} \mathrm{O}_{2}$ decomposes before complete oxidation of the sulfide occurs. In such cases, a sequence of the NAG tests is repeated until complete oxidation occurs. In samples with high organic contents $(>5 \%)$, the $\mathrm{H}_{2} \mathrm{O}_{2}$ can cause partial oxidation of the carbonaceous material in coal waste forming organic acids that contribute to net acidity, causing an overestimation of the sample acidity potential [35]. The extended boil protocol developed in Australia corrects for the effects of organic acid. However, aggressive boiling can also decompose free acidity [34,35].

\subsection{Analysis of Total Sulfur and Sulfur Forms in Coal}

The discussions above have highlighted the importance of developing a quantitative understanding of sulfur and its forms in coal wastes in the context of characterizing the potential for ARD generation. The most commonly used methods for total sulfur determination are the Eschka method (ASTM D1377, ISO 334:1993, SANS 334:1992), bomb washing (ASTM D-3286) and high-temperature combustion (ASTM D-4239, SABS 931) [13]. Sulfur is also determined by means of instrumental techniques, including ICP-AES/OES, ICP-MS, Ultraviolet-Visible Spectroscopy (UV-VIS) and chromatography, following complete digestion of the samples.

The most commonly used method to determine sulfur forms in coal and coal wastes is the International Organization for Standardization (ISO) 157:1996 protocol [13]. This protocol involves a two-stage sequential acid leach to determine sulfate sulfur and pyritic sulfur [13]. In the first leach step, dilute $\mathrm{HCl}$ is used to selectively dissolve the sulfate minerals, and the leachate analyzed for sulfate using the gravimetric $\mathrm{BaCl}_{2}$ method. In the second step, $\mathrm{HNO}_{3}$ is used to selectively solubilize the pyrite in the residue from the $\mathrm{HCl}$ digestion step, and the leachate subsequently analyzed for iron by means of atomic absorption spectroscopy (AAS), titration or colorimetric methods. Organic sulfur is then calculated by subtracting the sulfate sulfur and pyritic sulfur from the total sulfur content. The ISO 157:1996 protocol is based on a number of assumptions, one being that sulfate minerals are dissolved in the $\mathrm{HCl}$ leach step, with sulfide minerals and organic sulfur remaining in the solid phase. Another key assumption is that dilute $\mathrm{HNO}_{3}$ only dissolves pyritic iron and that pyrite is the only sulfide mineral in the sample [13]. Finally, all the unaccounted sulfur is assumed to be present as organic sulfur. Iron from the dissolution of iron silicates or iron oxides can cause overestimation of pyritic sulfur in the standard method, whilst incomplete extraction of pyritic sulfur by $\mathrm{HNO}_{3}$ can result in underestimation [43]. Elemental sulfur in the sample causes the overestimation of the organic sulfur because it is not extracted by either $\mathrm{HCl}$ or $\mathrm{HNO}_{3}$ [32]. The presence of jarosite species causes overestimation of pyritic sulfur and underestimation of sulfate sulfur, as jarosite is only partially soluble in $\mathrm{HCl}$, with the majority dissolving in $\mathrm{HNO}_{3}$ and reporting as pyrite [12]. High levels of $\mathrm{Ca}$ or $\mathrm{Ba}$ in the sample may result in the formation of insoluble $\mathrm{BaSO}_{4}$ or partially soluble $\mathrm{CaSO}_{4}$, thus lowering sulfate sulfur values [13].

A research project supported by the Australian Coal Association Research Program (ACARP) C15034 developed a sulfur speciation protocol that aimed to overcome most of the above-mentioned shortcomings of the ISO 157:1996 method. The ACARP C15034 protocol has been specifically developed 
for coal "washery" wastes. For routine determination of sulfur species in coal processing wastes, the protocol is performed in three stages, each conducted on a separate representative sub-sample. In the first stage, total sulfur is determined using the standard combustion method. In the next stage, the chromium reducible sulfur (CRS) method [32] is used to determine the sulfide sulfur content. In this method sulfide and elemental sulfur are selectively reduced by chromium to form $\mathrm{H}_{2} \mathrm{~S}$, which can be trapped in zinc acetate solution as ZnS. Although an acetone extraction step can be included to selectively remove and determine elemental sulfur [44], this is usually not necessary as coal processing wastes usually have only trace amounts of elemental sulfur [33]. In the third stage, all sulfate minerals (except jarosite) are selectively dissolved in the $\mathrm{KCl}$ solution and the filtrate separated into two portions. One portion is used to determine total sulfate, using the gravimetric $\mathrm{BaCl}_{2}$ method, and the other to determine soluble acid-forming sulfates (such as melanterite) through back-titration with $\mathrm{NaOH}[33,34,44]$. The remaining sulfur, which includes organic sulfur and sulfur present as jarosite, is termed "low-risk" sulfur.

This study sets out to evaluate and compare these methods for analyzing sulfur and sulfur species in South African coal processing wastes, and to investigate the implications of sulfur speciation and the behavior of sulfur forms on the classification of the ARD potential when using standard static laboratory tests.

\section{Experimental Work}

\subsection{Sample Description and Preparation}

To test a range of coal processing wastes, test work was conducted on three samples from different South African coalfields and processing stages: an ultrafine $(\mathrm{d} 80<150 \mu \mathrm{m})$ thickener feed slurry from a colliery in Waterberg coalfield (sample A) and an ultrafine $(\mathrm{d} 80<150 \mu \mathrm{m})$ thickener underflow slurry sample (sample B) and a coarse discard (d80 $>25 \mathrm{~mm}$ ) sample (sample C) from a colliery in the Witbank coalfield. These samples were collected as grab samples and can thus be considered typical, but not necessarily representative, of the coalfields and operations from which they were collected. For reference, a South African (Free State) coal standard reference material, SARM 19, was used to assess the reproducibility and accuracy of the total sulfur methods. The air-dried samples were pulverized to $-75 \mu \mathrm{m}$ and split to the required amounts according to the test. The experimental work consisted of the analysis of total sulfur and sulfur forms, semi-quantitative mineralogical analysis, and ARD geochemical tests.

\subsection{Mineralogical Analysis}

A semi-quantitative analysis of the mineralogical composition of the three coal waste samples was carried out using a Field Emission Gun (FEG) Quantitative Evaluation of Minerals by Scanning Electron Microscopy (QEMSCAN) 650F machine with two XFlash 6130 detectors (manufactured by Bruker, Billerica, MA, USA). Bruker detectors use electron dispersion scatter (EDS) detection to measure elements. These element concentration values can be seen in the iDiscover programme for each Pixel measured. The QEMSCAN then uses a mineral library system, called the species identification protocol (SIP), to determine how the elemental information measured by the detectors is classified into a mineralogical composition or species. The carbon-coated sample blocks were put in a Quorum Q150€ coater to disperse the electron charge. The results of this analysis are considered to be semi-quantitative, as the SIP file for Waterberg and Witbank coal is still under development.

\subsection{Total Sulfur Analysis}

The total sulfur was determined using the standard gravimetric Eschka method (SANS 334:1992/ISO 334/1992) and the standard combustion method (ASTM D-4239, sub-method C; SABS method 931) using a LECO analyser SC 632. All tests were performed in triplicate by the same person for repeatability indication. The standard error analysis gave the precision of the method, and a relative 
standard error (RSE) of the SARM 19 results relative to certified values allowed for assessment of the accuracy of the methods.

\subsection{Sulfur Speciation}

The standard ISO 157:1996 protocol was conducted by ALS laboratories to determine the sulfur forms in the coal wastes and the coal standard. Analyses were conducted on three representative sub-samples over a protracted period. The ACARP C15034 protocol [33], was applied in-house to determine sulfide sulfur, total soluble sulfate and soluble acid-forming sulfate in the three coal waste samples and the residues from the leach stages of the standard ANC and NAG tests outlined in Section 2.5. Organic/low-risk sulfur content for the two protocols was calculated by difference, using the total sulfur results obtained from the LECO analysis (Section 2.3).

\subsection{Characterisation of ARD Potential}

The ARD potential of the wastes was determined using the conventional ABA and NAG tests, as well as the extended boil NAG test. In the ABA test, ANC was determined using the incremental $\mathrm{H}_{2} \mathrm{O}_{2}$ Modified Sobek method [45]. The MPA was calculated on the basis of total sulfur content determined by LECO analysis (Section 2.3), pyritic sulfur as determined by the ISO 157:1996 protocol, and acid-generating sulfur (sulfide and acid-forming sulfate sulfur) as determined using the ACARP C15034 protocol (Section 2.4). The NAG pH was determined using the single addition NAG [36] and the extended boil NAG protocol [34]. All the tests were conducted in triplicate.

\subsection{Deportment of Sulfur Forms under ARD Test Conditions}

The three waste samples were digested according to the ANC and NAG test methods, and the residues dried and analyzed for total sulfur and sulfur forms using LECO analysis and the ACARP C15034 method, respectively. The results were compared to the content of sulfur species in the waste samples before digestion to calculate their deportment under static test leach conditions.

\section{Results and Discussion}

\subsection{Mineralogical Composition}

Generally, the coal processing wastes were found to be made up of predominantly of coal (19-45\%), carbominerite (coal made of 20-60\% mineral matter content and 40-80\% organic content; varying from 6-30\%), quartz $\left(\mathrm{SiO}_{2} ; 3-21 \%\right)$, kaolinite $\left(\mathrm{Al}_{2} \mathrm{Si}_{2}(\mathrm{OH})_{4} ; 21-52 \%\right)$, pyrite $\left(\mathrm{FeS}_{2} ; 1.8-2.7 \%\right)$ and k-feldspar $\left(\mathrm{KAlSi}_{3} \mathrm{O}_{8} ; 0.6-2 \%\right)$. Whilst pyrite was the major sulfide mineral in all the samples, chalcopyrite $\left(\mathrm{CuFeS}_{2}<0.5 \%\right)$ was also identified in the Waterberg slurry and Witbank discard wastes. Identified sulfate minerals included trace amounts of gypsum $\left(\mathrm{CaSO}_{4} \cdot 2 \mathrm{H}_{2} \mathrm{O}<0.2 \%\right)$ in the two slurry wastes, and jarosite $\left(\mathrm{KFe}_{3}\left(\mathrm{SO}_{4}\right)_{2}(\mathrm{OH})_{6} ; 0.01 \%\right)$ in the Waterberg slurry waste. No other sulfates, such as alunite $\left(\mathrm{KAl}_{3}\left(\mathrm{SO}_{4}\right)_{2}(\mathrm{OH})_{6}\right)$ or melanterite $\left(\mathrm{FeSO}_{4} \cdot 7 \mathrm{H}_{2} \mathrm{O}\right)$, were detected. Only the Waterberg slurry waste contained a significant quantity of carbonate, in the form of calcite $\left(\mathrm{CaCO}_{3} ; 1.4 \%\right)$, with trace amounts occurring in the Witbank coal slurry $(<0.05 \%)$. Amphibole, generally considered to be a silicate of intermediate reactivity, was identified as being present in significant quantities in the Waterberg slurry waste $(\sim 0.7 \%)$ and in trace quantities $(<0.05 \%)$ in the Witbank slurry wastes. Other minor-trace minerals identified in the coal wastes included the silicate mineral mica $\left(\mathrm{K}_{2} \mathrm{Al}_{4} \mathrm{Si}_{6} \mathrm{Al}_{2} \mathrm{O}_{20}(\mathrm{OH})_{4}\right)$, the non-neutralizing carbonate mineral, siderite $\left(\mathrm{FeCO}_{3}\right)$, and the complex oxide minerals, iron oxyhydroxides, rutile $\left(\mathrm{TiO}_{2}\right)$ and apatite $\left(\mathrm{Ca}_{5}\left(\mathrm{PO}_{4}\right)_{3}(\mathrm{OH}, \mathrm{F}, \mathrm{Cl})\right)$.

\subsection{Total Sulfur Content}

The results in Table 3 show that the sulfur content in the samples analysed decreases in the order Witbank discards $<$ Waterberg slurry $<$ SARM 19 standard $<$ Witbank slurry. Whilst all the values were within the general range reported for South African coal wastes (c.f. Table 1), the sulfur content in the 
Witbank coal slurry (1.06-1.11\%) was significantly lower than that reported for previous slurry wastes from a different colliery in the Witbank coalfields (4.18\%) [14]. This is consistent with the reported variance in the sulfur content of different coal seams within this region [4].

Table 3. Total sulfur contents in coal standard SARM 19 and coal waste samples determined by the Eschka method and LECO analysis.

\begin{tabular}{ccc}
\hline \multirow{2}{*}{ Sample } & \multicolumn{2}{c}{ Total S Content (Mass \%) } \\
\cline { 2 - 3 } & LECO Method & Eschka Method \\
\hline SARM 19 & $1.54 \pm 0.03$ & $1.30 \pm 0.02$ \\
Waterberg coal slurry & $1.84 \pm 0.01$ & $1.89 \pm 0.01$ \\
Witbank coal slurry & $1.06 \pm 0.06$ & $1.11 \pm 0.05$ \\
Witbank coal discards & $1.94 \pm 0.08$ & n.d. \\
\hline
\end{tabular}

A comparison of total sulfur results with the certified value for the coal standard SARM 19 (Table 4), indicates that the LECO and Eschka methods gave comparable results with low standard errors (range of $0.01-0.03 \%$ ), indicating the methods were highly precise. However, whilst the LECO results are consistent with the $95 \%$ confidence limit range reported for the certified coal standard with a relative standard error of $3.13 \%$, the relative error for the Eschka test results was over $12 \%$.

Table 4. The relative standard error of total sulfur analyzing techniques based on coal standard SARM 19 certified values.

\begin{tabular}{cccccc}
\hline \multicolumn{2}{c}{ Certified Values (\%) } & \multicolumn{2}{c}{ Mean Measured Values (\%) } & \multicolumn{2}{c}{ Relative Error (\%) } \\
\hline Mean & $95 \%$ Confidence Limit & LECO-ALS & Eschka & LECO-ALS & Eschka \\
1.49 & $1.42-1.55$ & $1.54 \pm 0.03$ & $1.30 \pm 0.02$ & 3.13 & -12.53 \\
\hline
\end{tabular}

\subsection{Sulfur Speciation Results}

The sulfur speciation results obtained for the two chemical protocols, ISO 157:1996 and ACARP C15034, are shown in Table 5 and Figure 1.

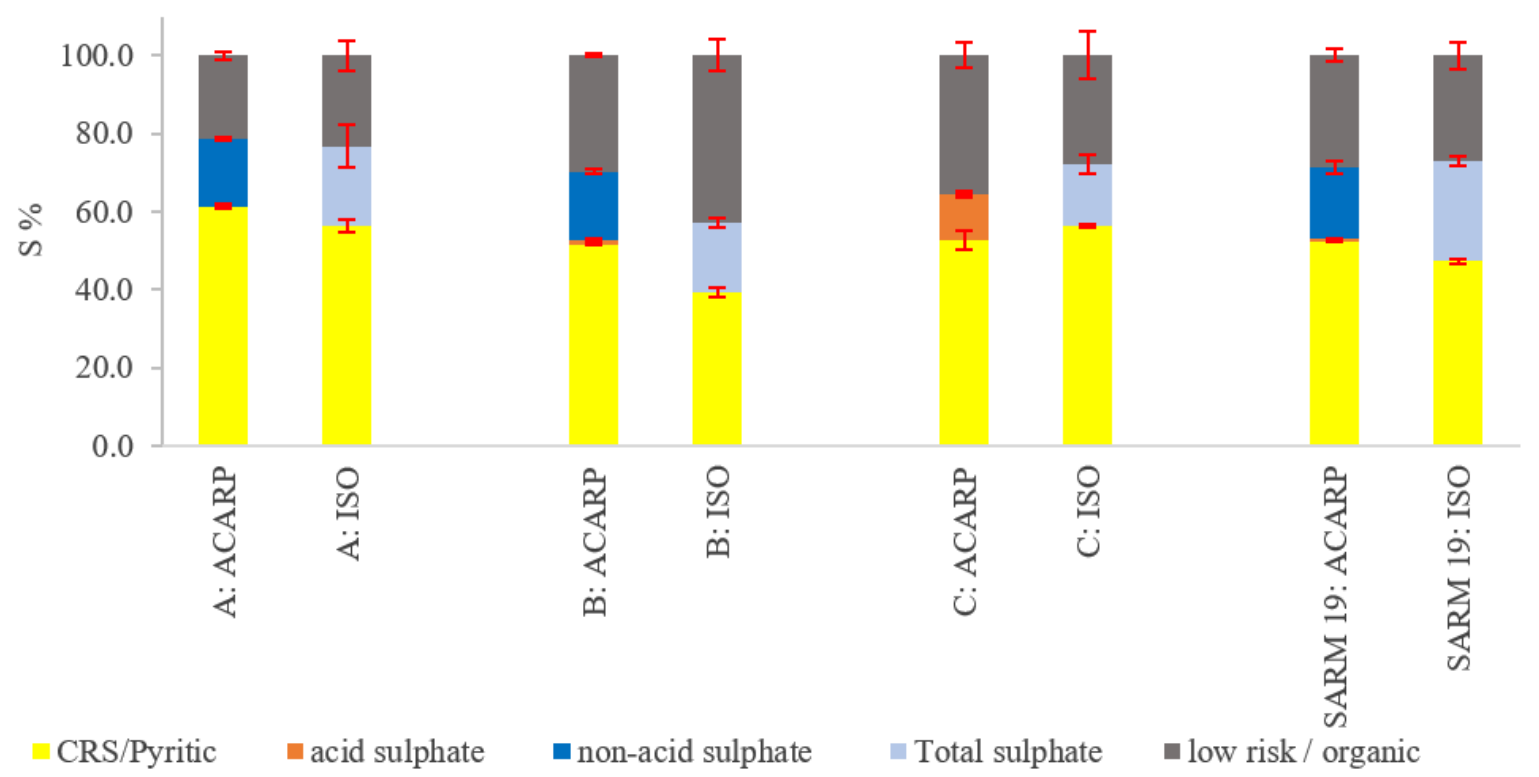

Figure 1. Distribution of sulfur forms in coal standard SARM 19 and coal waste samples A (Waterberg coal slurry), B (Witbank coal slurry) and C (Witbank coal discards) by ISO 157:1996 and ACARP C15034 protocols. 
Table 5. The concentration of sulfur forms in coal standard (SARM 19) and coal waste samples determined by ISO 157:1996 and ACARP C15034 protocols.

\begin{tabular}{|c|c|c|c|c|c|c|c|c|}
\hline \multirow{3}{*}{ Sulfur Form } & \multicolumn{8}{|c|}{ Mass (\%) of Sulfur Form in Sample } \\
\hline & \multicolumn{2}{|c|}{ Waterberg Coal Slurry } & \multicolumn{2}{|c|}{ Witbank Coal Slurry } & \multicolumn{2}{|c|}{ Witbank Coal Discards } & \multicolumn{2}{|c|}{ SARM 19} \\
\hline & ACARP & ISO & ACARP & ISO & ACARP & ISO & ACARP & ISO \\
\hline CRS/Pyritic ${ }^{1}$ & $1.13 \pm 0.01$ & $1.04 \pm 0.02$ & $0.55 \pm 0.00$ & $0.42 \pm 0.01$ & $1.02 \pm 0.03$ & $1.10 \pm 0.01$ & $0.80 \pm 0.00$ & $0.73 \pm 0.01$ \\
\hline Acid sulfate $^{2}$ & $0.00 \pm 0.00$ & - & $0.01 \pm 0.00$ & - & $0.23 \pm 0.01$ & - & $0.01 \pm 0.00$ & - \\
\hline Non-acid sulfate ${ }^{3}$ & $0.32 \pm 0.00$ & - & $0.19 \pm 0.00$ & - & - & - & $0.28 \pm 0.02$ & $0.39 \pm 0.01$ \\
\hline Total Sulfate & $0.32 \pm 0.00$ & $0.37 \pm 0.06$ & $0.20 \pm 0.00$ & $0.19 \pm 0.01$ & $0.23 \pm 0.01$ & $0.31 \pm 0.02$ & $0.29 \pm 0.02$ & $0.39 \pm 0.01$ \\
\hline Low-risk ${ }^{4} /$ organic & $0.39 \pm 0.01$ & $0.43 \pm 0.04$ & $0.32 \pm 0.00$ & $0.45 \pm 0.04$ & $0.69 \pm 0.03$ & $0.54 \pm 0.06$ & $0.44 \pm 0.02$ & $0.42 \pm 0.03$ \\
\hline
\end{tabular}

${ }^{1}$ Determined as pyritic sulfur in ISO 157:1996 protocol and as chromium reducible sulfide (CRS) sulfur in ACARP C15034 protocol. ${ }^{2}$ Not determined in ISO157:1996 protocol. ${ }^{3}$ Not determined in ISO157:1996 protocol. ${ }^{4}$ Calculated from the difference between total sulfur and sum of sulfate and sulfide/pyritic sulfur values. 
Consistent with the findings of [16], the results in Figure 1 show that, in general, pyritic or sulfide sulfur accounts for more than $50 \%$ of the total sulfur. Sulfate sulfur accounts for $18-26 \%$ of the total sulfur for the coal standard (SARM 19) and both the coal slurry wastes, but only $12-15 \%$ of total sulfur for the Witbank coal discards. The ACARP test results indicate, furthermore, that all the soluble sulfate in Witbank coal discards is present as acid-forming soluble sulfate minerals (e.g., melanterite), whilst in the case of the Waterberg and Witbank slurry wastes and the SARM standard, the majority of the soluble sulfate sulfur $(100 \%, 95.5 \%$ and $98.8 \%$, respectively) is present as non-acid forming sulfates (e.g., gypsum and epsomite). The contribution of the remaining sulfur species, comprised mainly of organic sulfur, varies between $18 \%$ and $43 \%$, with the proportion of organic sulfur being lowest in the Waterberg coal slurry waste (18-20\%) and highest in Witbank coal discards (23-43\%).

The sulfide or pyritic sulfur and soluble sulfate sulfur results are compared graphically in Figures 2 and 3, respectively. The results show that the standard ISO 157:1996 protocol resulted in lower sulfide sulfur values than the ACARP C15034 protocol for all samples except the Witbank discards. Conversely, in the case of sulfate sulfur, the standard ISO 157:1996 protocol resulted in slightly higher values than the ACARP C15034 protocol for all samples except the Witbank coal slurry (for which the results derived from both protocols were equivalent). The higher sulfate and lower pyritic sulfur values obtained for the ISO 157:1996 protocol in comparison to the ACARP C15034 protocol for the majority of the samples indicate that the relatively aggressive $\mathrm{HCl}$ leach may have resulted in some dissolution of sulfide or pyritic sulfur, thus overestimating the sulfate sulfur and underestimating the pyritic sulfur contents in the case of the ISO 157:1996 protocol. It is unclear why the ISO 157:1996 protocol resulted in higher sulfide sulfur values than the ACARP C15034 protocol in the case of the Witbank discards sample. This may possibly be due to partial dissolution of relatively stable Fe-bearing mineral phases other than pyrite (e.g., chalcopyrite and jarosite) during the $\mathrm{HNO}_{3}$ leach step, resulting in an overestimation of the sulfide sulfur. However, whilst the mineralogical analysis indicated that this sample contains higher quantities of chalcopyrite than the other coal waste samples, there was no evidence of elevated jarosite concentrations. It should, furthermore, be noted that discrepancies between the two methods are relatively minor (mostly $<10 \%$ ), especially for sulfide sulfur. The results also indicate that, with the exception of one result (ISO 157:1996 total sulfate in the Waterberg slurry waste), the standard deviations obtained for both protocols were generally $<10 \%$.

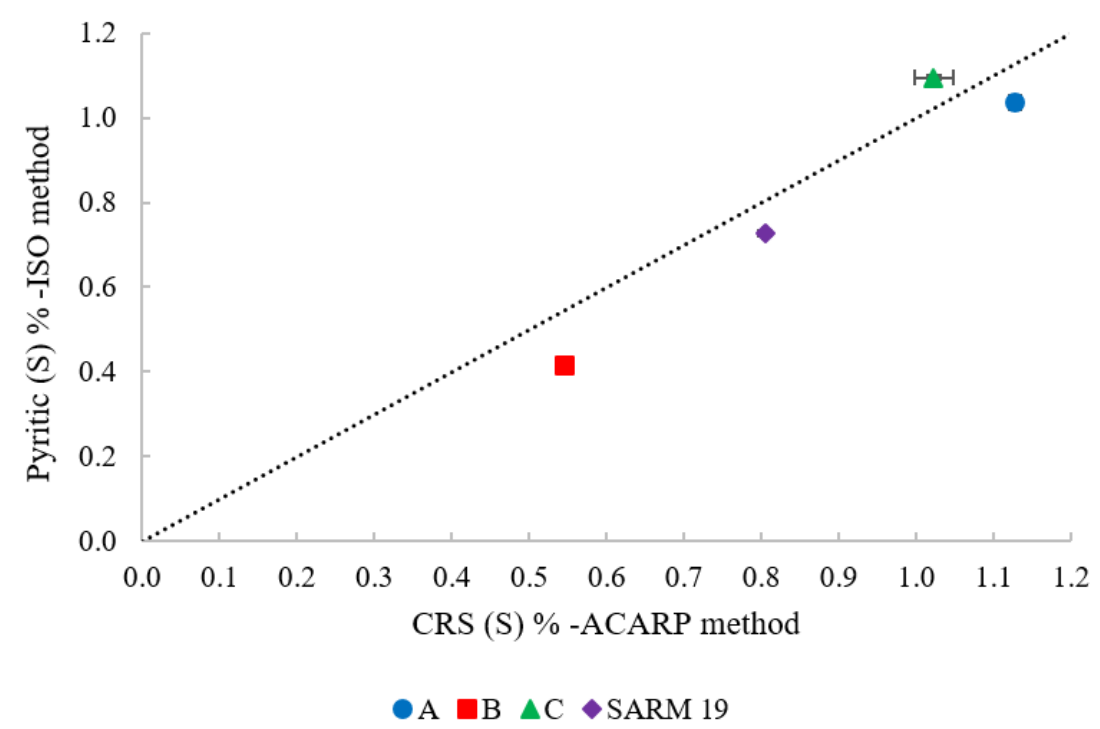

Figure 2. Comparison of ISO157:1996 and ACARP C15034 protocols in determining pyritic/sulfide sulfur on coal standard SARM 19 and coal waste samples A (Waterberg coal slurry), B (Witbank coal slurry) and C (Witbank coal discards). 


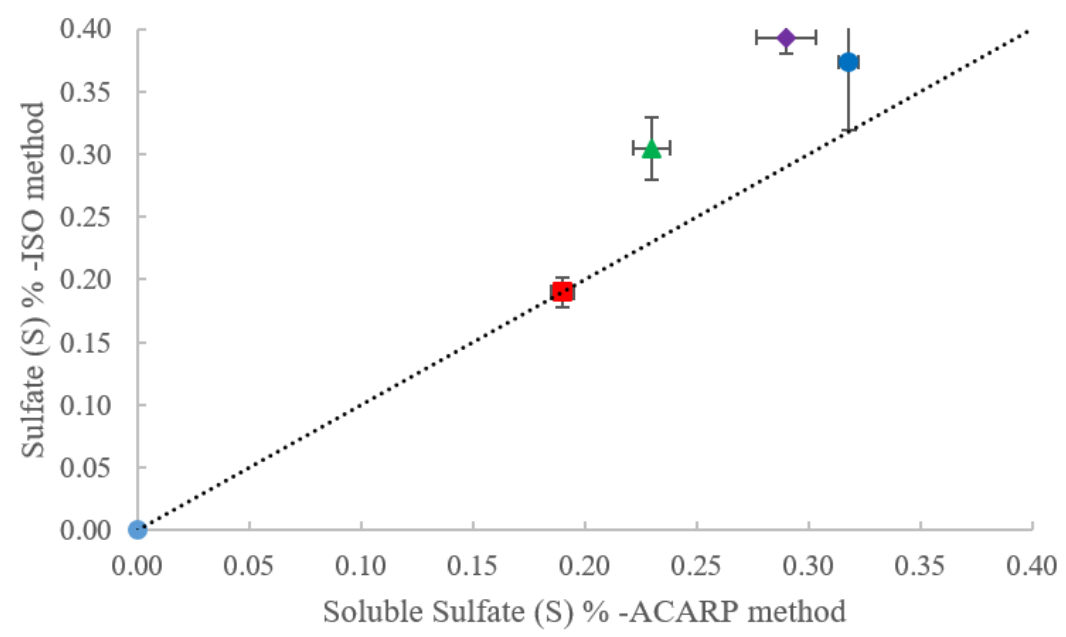

-A $\square \triangle \mathrm{B} \bullet \mathrm{SARM} 19$

Figure 3. Comparison of ISO157:1996 and ACARP C15034 methods in determining sulfate sulfur on coal standard SARM 19 and coal waste samples A (Waterberg coal slurry), B (Witbank coal slurry) and C (Witbank coal discards).

\subsection{The Implication of Sulfur Species on ARD Classification}

The results for the static acid-base accounting (ABA) and net acid generation (NAG) tests for the classification of ARD potential are presented in Table 6, where the maximum potential acidity (MPA) and net acid-producing potential (NAPP) for the ABA tests have been calculated on the basis of total sulfur ( $\mathrm{S}(\mathrm{T})$, as determined by means of LECO), pyritic sulfur ( $\mathrm{S}^{2-}$, as determined by means of the ISO 157:1996 protocol), as well as acid-forming sulfur (S (AF)), as determined by means of the ACARP C15034 protocol. The results in Table 6 indicate that the MPA and NAPP values calculated on the basis of pyritic and acid-forming sulfur are significantly lower than those calculated on the basis of total sulfur.

Table 6. Acid-base accounting and net acid generation test results for coal waste samples.

\begin{tabular}{|c|c|c|c|c|}
\hline Parameter & Derivation & $\begin{array}{c}\text { Waterberg Coal } \\
\text { Slurry }\end{array}$ & $\begin{array}{l}\text { Witbank Coal } \\
\text { Slurry }\end{array}$ & $\begin{array}{l}\text { Witbank } \\
\text { Discards }\end{array}$ \\
\hline \multirow{3}{*}{ Sulfur content (\%) } & LECO S (T) & 1.84 & 1.06 & 1.94 \\
\hline & ISO $\mathrm{S}^{2-}$ & 1.04 & 0.42 & 1.10 \\
\hline & ACARP S (AF) & 1.13 & 0.56 & 1.25 \\
\hline \multirow{3}{*}{$\mathrm{MPA}\left(\mathrm{kg} \mathrm{H}_{2} \mathrm{SO}_{4} / \mathrm{t}\right)$} & LECO S (T) & 56.30 & 32.44 & 59.36 \\
\hline & ISO S ${ }^{2-}$ & 31.84 & 12.85 & 33.66 \\
\hline & ACARP S (AF) & 34.52 & 17.14 & 38.27 \\
\hline ANC & Modified Sobek & 102.30 & 29.21 & 29.10 \\
\hline \multirow{3}{*}{$\operatorname{NAPP}\left(\mathrm{kg} \mathrm{H}_{2} \mathrm{SO}_{4} / \mathrm{t}\right)$} & LECO S (T) & -46.79 & 3.22 & 30.26 \\
\hline & $\mathrm{ISO} \mathrm{S}^{2-}$ & -71.27 & -16.36 & 4.56 \\
\hline & ACARP S (AF) & -68.27 & -12.08 & 9.17 \\
\hline \multirow{2}{*}{ NAG pH } & Standard NAG & 5.20 & 3.90 & 2.56 \\
\hline & Extended boil NAG & $\mathrm{n} / \mathrm{a}$ & 5.20 & 2.59 \\
\hline
\end{tabular}

Where: $\mathrm{T}(\mathrm{S})=$ total sulfur, as determined by LECO; $\mathrm{S}^{2-}=$ pyritic sulfur as determined by the ISO 157:1996 protocol; $\mathrm{S}(\mathrm{AF})=$ acid-forming sulfur as determined by the ACARP protocol C15034 and is based on the content of CRS sulfide sulfur and the acid-forming soluble sulfate; MPA = maximum potential acidity; $\mathrm{ANC}=$ acid-neutralizing capacity; NAPP = net acid-producing potential; NAG = net acid generating.

A more detailed comparison (Figure 4) of the calculated MPA values indicates, furthermore, that the MPA values based on the pyritic sulfur content as derived from the ISO 157:1996 protocol are lower 
(between 2.7 and $4.6 \mathrm{~kg} \mathrm{H}_{2} \mathrm{SO}_{4} / \mathrm{t}$ than those based on the acid-forming sulfur content as derived from the ACARP C15034 protocol. As discussed in the previous section, this can be largely attributed to the underestimation of the pyritic sulfur in the case of the ISO 157:1996 protocol. This difference is, furthermore, slightly larger for the Witbank discards (sample C) which contain significant quantities of acid-forming sulfate, not accounted for by the standard ISO 157:1996 protocol.

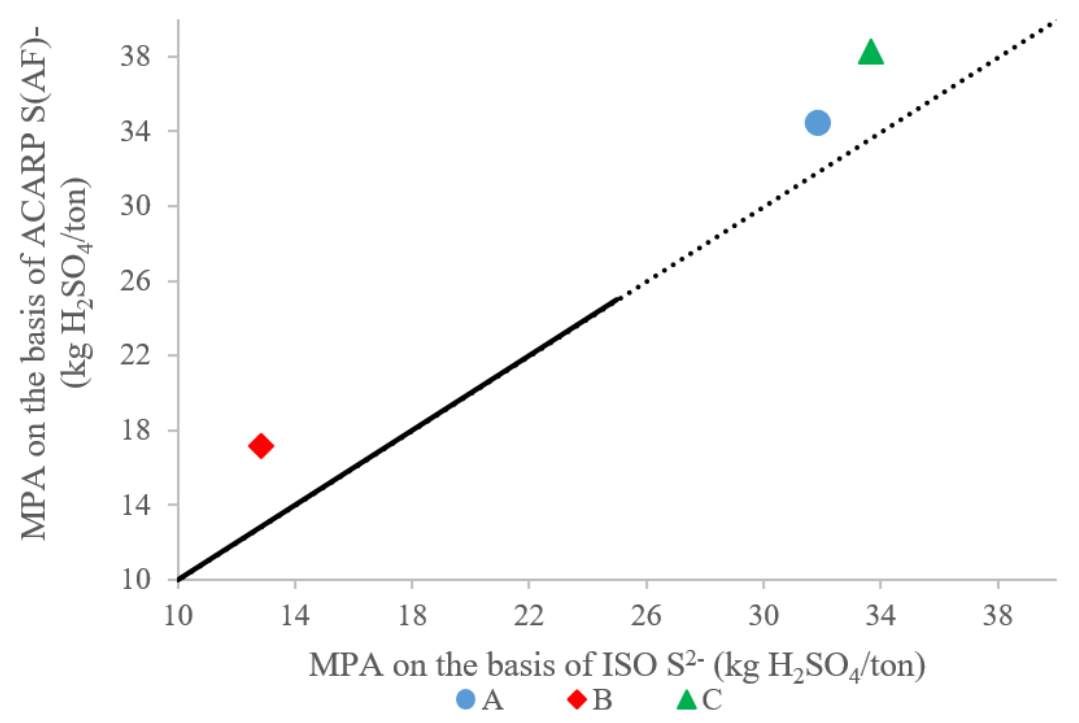

Figure 4. Comparison of maximum potential activity (MPA) values determined from ACARP C15034 acid-forming sulfur (S (AF)) and ISO157:1996 pyritic sulfur $\left(\mathrm{S}^{2-}\right)$ for the coal waste samples A (Waterberg coal slurry), B (Witbank coal slurry) and C (Witbank coal discards).

The combined ABA-NAG classification plot in Figure 5 indicates that the classification of the Waterberg coal slurry remained non-acid forming (NAF), with a negative NAPP and a NAG $\mathrm{pH}>4.5$, for all test cases. This can be attributed to the high experimentally-derived acid-neutralizing capacity (ANC) relative to the acid-forming sulfur content. Conversely, the classification of the Witbank discard sample remains potentially acid-forming (PAF), with a positive NAPP and a NAG $\mathrm{pH}<4.5$, for all test cases. The results in Table 6 and Figure 5 also confirm that the changes in the NAG pH on including an extended boil step were insignificant, indicating the negligible formation of organic acids under NAG test conditions.

In contrast to the Waterberg slurry and Witbank discard wastes, the classification of the Witbank coal slurry varied, depending on the test conditions and parameters. Standard NAG and ABA tests, with the NAPP calculated on the basis of total sulfur, give rise to a PAF classification. When calculating the NAPP on the basis of pyritic or acid-forming sulfur contents, the NAPP becomes negative, resulting in an "uncertain" or inconclusive classification. Furthermore, the NAG pH increased from a value of 3.9 to 5.2 during the extended boil step, changing the classification from PAF to uncertain when using total sulfur to calculate the MPA in the ABA tests, and from uncertain to NAF when using pyritic sulfur or acid-forming sulfur to calculate MPA. In contrast to the Witbank discards, the change in NAG $\mathrm{pH}$ during the extended boil is indicative of significant organic acid formation under the relatively aggressive NAG leach conditions. Although resulting in slightly higher NAPP values, the use of the ISO-derived sulfide sulfur, as opposed to the ACARP-derived acid-forming sulfur, did not affect the classification of the coal waste samples in any of the cases investigated in this study.

\subsection{Conversion of Sulfur Species under ARD Static Tests}

As indicated in Section 2.6, ACARP C15034 sulfur speciation tests were also conducted on the leach residues from the static chemical tests in order to assess the behavior of the various sulfur forms during the leach stages. The results in Figure 6 show that under ANC leach conditions, the CRS 
sulfide sulfur content in the solids decreased by $21 \%, 50 \%$ and $17 \%$ in the case of the Waterberg coal slurry, Witbank coal slurry and Witbank coal discard samples respectively. In the case of the slurry waste samples, results are indicative of partial conversion of sulfide sulfur to acid-forming sulfate (e.g., melanterite) and low-risk sulfur forms (e.g., jarosite and elemental sulfur), whilst in the case of the Witbank discard sample, a net decrease in the acid-forming soluble sulfate and low-risk sulfur can probably be attributed to both the formation and subsequent dissolution of acid-forming soluble sulfates and jarosite over the duration of the leach test. The conversion of sulfide sulfur, as well as the dissolution of acid-forming sulfates such as melanterite and jarosite, generate acid, thus resulting in an underestimation of the ANC values, in the order of 4.5-5.5 $\mathrm{kg} \mathrm{H}_{2} \mathrm{SO}_{4} / \mathrm{t}$ in the case of the slurry wastes, and $10-12 \mathrm{~kg} \mathrm{H}_{2} \mathrm{SO}_{4} / \mathrm{t}$ in the case of the Witbank discards.

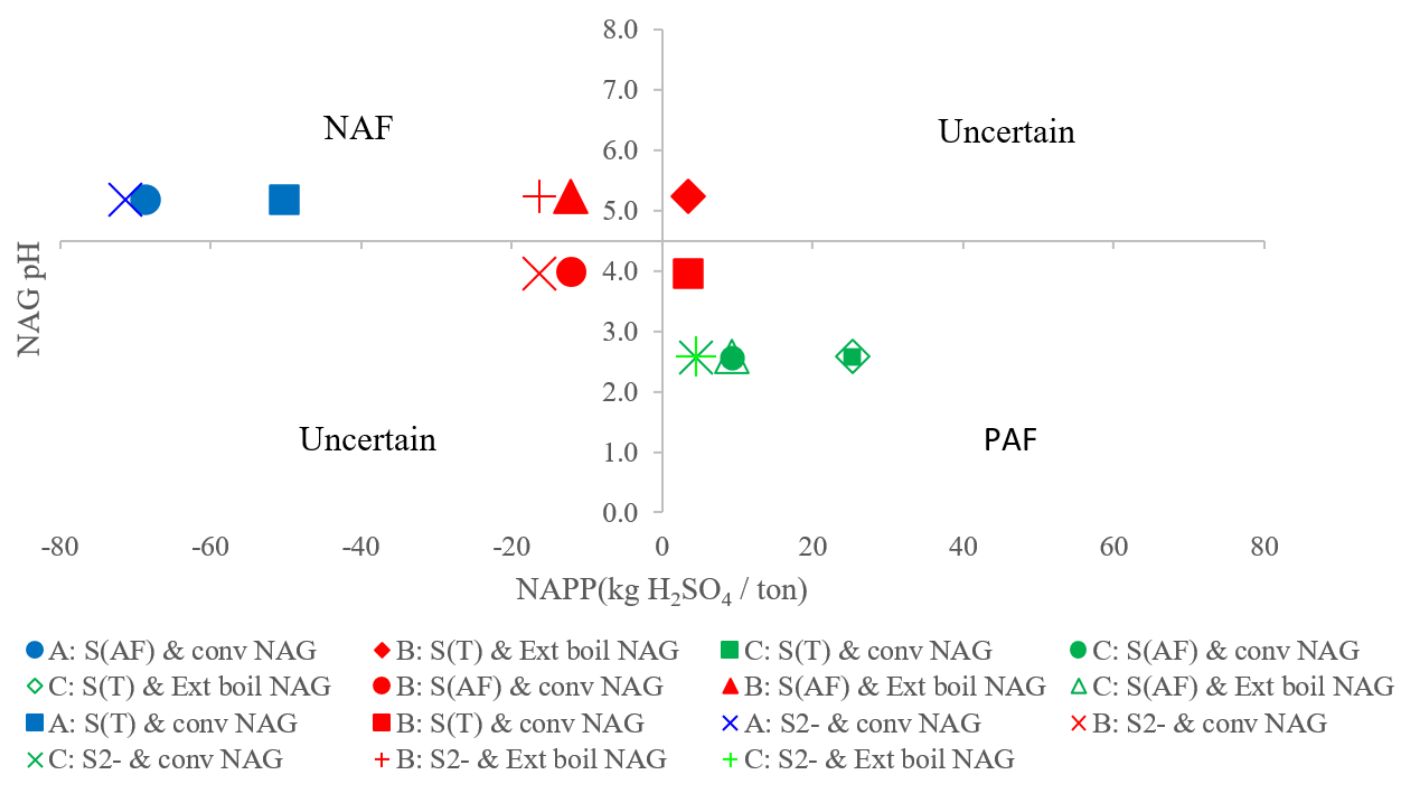

Figure 5. Classification of the acid-rock drainage (ARD) potential of coal waste samples A (Waterberg coal slurry), B (Witbank coal slurry) and C (Witbank coal discards) by conventional (conv) NAG and extended (Ext) boil net acid generation (NAG) tests in combination with acid-base accounting (ABA) tests considering LECO total sulfur S (T), ISO 157:1996 pyritic sulfur $\left(\mathrm{S}^{2-}\right)$ and ACARP C15034 acid-forming sulfur $S(A F)$.

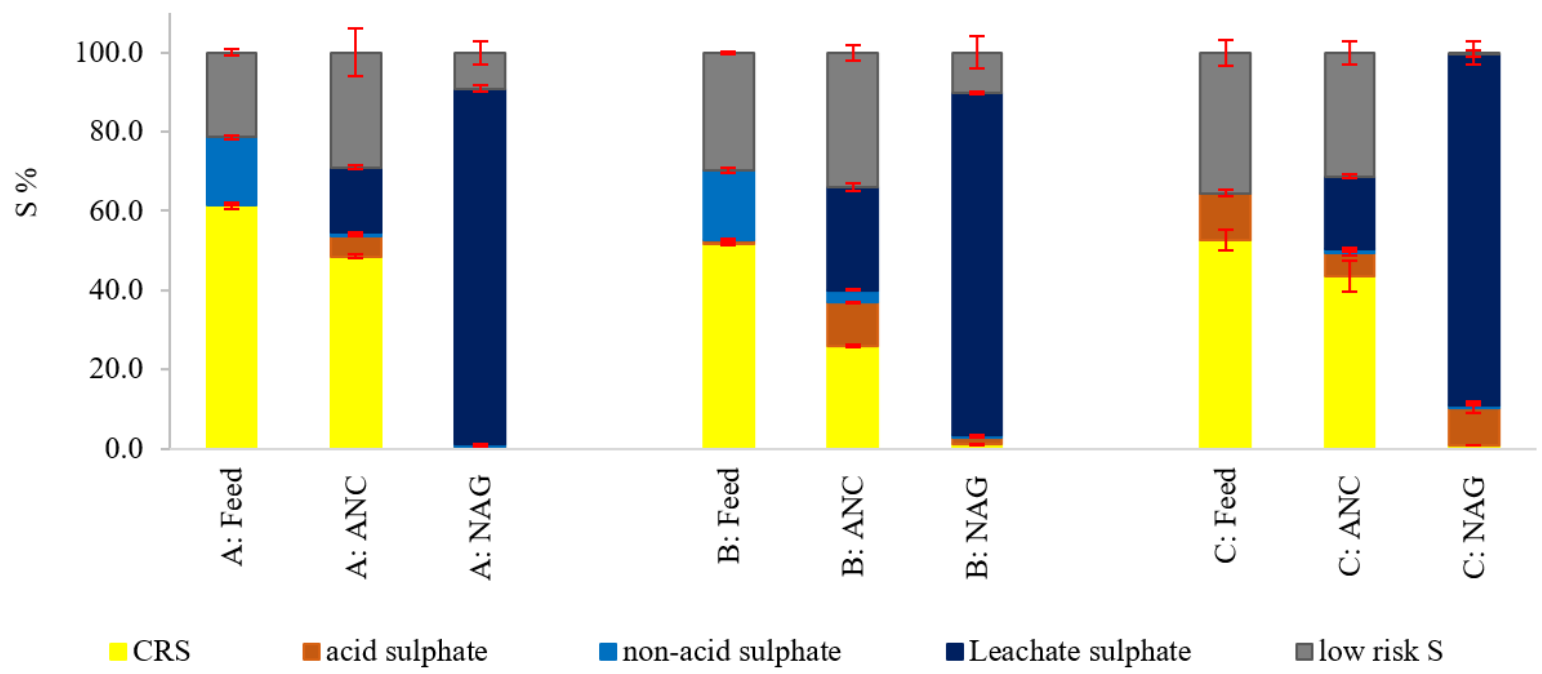

Figure 6. Conversion of sulfur species in coal waste samples A (Waterberg coal slurry), B (Witbank coal slurry) and C (Witbank coal discards) under acid-neutralizing capacity (ANC) and NAG static test conditions. 
In the case of the slurry waste samples, the conversion of sulfur species during ANC leaching is relatively low and is thus unlikely to have influenced the classification of the samples. However, the relatively significant effect on ANC in the case of the Witbank discards may have resulted in a change in classification from "uncertain" to acid-forming. This relatively large effect can be largely attributed to the dissolution of acid-forming soluble sulfate, which accounted for up to $7.0 \mathrm{~kg} \mathrm{H}_{2} \mathrm{SO}_{4} / \mathrm{t}(60 \%$ of the additional acid formation) for the Witbank discard waste. The possible reactions of sulfur minerals under ANC leach conditions and associated quantities of acid produced on the basis of the conversion of sulfur forms are presented in Table 7.

Table 7. Possible reactions of sulfur species under ANC test conditions and the estimated quantities of acid produced (A: Waterberg coal slurry, B: Witbank coal slurry, C: Witbank discards).

\begin{tabular}{|c|c|c|c|}
\hline \multirow[t]{2}{*}{ Reaction Equations } & \multicolumn{3}{|c|}{$\begin{array}{l}\text { Amount of Acid Produced } \\
\left(\mathrm{kg} \mathrm{H}_{2} \mathrm{SO}_{4} / \mathrm{t}\right)\end{array}$} \\
\hline & A & B & $\mathrm{C}$ \\
\hline $\mathrm{FeS}_{2}+\frac{45}{4} \mathbf{O}_{2}+\frac{15}{2} \mathbf{H}_{2} \mathbf{O}+\mathbf{K}^{+} \rightarrow \mathbf{K F e}_{3}\left(\mathbf{S O}_{4}\right)_{2}(\mathbf{O H})_{6}+4 \mathbf{S O}_{4}{ }^{2-}+9 \mathbf{H}^{+}$ & 3.27 & 0.92 & 0.00 \\
\hline $\mathrm{FeS}_{2}+\frac{7}{2} \mathbf{O}_{2}+\mathrm{H}_{2} \mathrm{O} \rightarrow \mathrm{FeSO}_{4}+\mathrm{H}_{2} \mathrm{SO}_{4}$ & 1.38 & 1.53 & 1.68 \\
\hline $\mathrm{FeS}_{2}+\frac{15}{4} \mathbf{O}_{2}+\frac{7}{2} \mathbf{H}_{2} \mathbf{O} \rightarrow \mathbf{F e}(\mathbf{O H})_{3}+2 \mathbf{H}_{2} \mathbf{S O}_{4}$ & 0.00 & 3.06 & $1.23-4.60$ \\
\hline $\mathbf{K F e}_{3}\left(\mathbf{S O}_{4}\right)_{2}(\mathbf{O H})_{6}+3 \mathbf{H}_{2} \mathbf{O} \rightarrow 3 \mathbf{F e}(\mathbf{O H})_{3}+\mathbf{K}^{+}+2 \mathbf{S O}_{4}{ }^{2-}+3 \mathbf{H}^{+}$ & 0.00 & 0.00 & 1.83 \\
\hline $\mathrm{FeSO}_{4}+\frac{1}{2} \mathbf{O}_{2}+\frac{5}{2} \mathbf{H}_{2} \mathbf{O} \rightarrow \mathbf{F e}(\mathbf{O H})_{3}+\mathbf{H}_{2} \mathbf{S O}_{4}$ & 0.00 & 0.00 & $3.70-7.04$ \\
\hline
\end{tabular}

The NAG leach tests resulted in the oxidative dissolution of the majority of the CRS sulfide sulfur (99.9\%, 95.8\% and $98.5 \%$ in the case of the Waterberg coal slurry, Witbank coal slurry and Witbank coal discards, respectively). The relatively aggressive NAG conditions, however, also resulted in a significant dissolution of low-risk sulfur, amounting to $53 \%, 38 \%$ and $99 \%$ in the case of the Waterberg coal slurry, Witbank coal slurry and Witbank coal discards respectively. This dissolution may result in an overestimation of the acid generating potential of the sample, particularly in the case of the Witbank discards. Organic sulfur compounds, such as thiols, sulfides and disulfides, can be oxidized by $\mathrm{H}_{2} \mathrm{O}_{2}$ to form sulfonic acid as shown by Equations (14) and (15) [46]:

$$
\begin{gathered}
\mathrm{R}-\mathrm{SH} \stackrel{\mathrm{H}_{2} \mathrm{O}_{2}}{\rightarrow} \mathrm{R}-\mathrm{S}-\mathrm{S}-\mathrm{R} \stackrel{\mathrm{H}_{2} \mathrm{O}_{2}}{\rightarrow} \mathrm{R}-\mathrm{SO}-\mathrm{SO}-\mathrm{R} \stackrel{\mathrm{H}_{2} \mathrm{O}_{2}}{\rightarrow} \mathrm{R}-\mathrm{SO}-\mathrm{SOO}-\mathrm{R} \stackrel{\mathrm{H}_{2} \mathrm{O}}{\rightarrow} \mathrm{R}-\mathrm{SO}_{3} \mathrm{H}, \\
\mathrm{R}_{2} \mathrm{~S} \stackrel{\mathrm{H}_{2} \mathrm{O}_{2}}{\rightarrow} \mathrm{R}_{2} \mathrm{SO}_{2} \stackrel{\mathrm{H}_{2} \mathrm{O}_{2}}{\rightarrow} \mathrm{R}_{2} \mathrm{SO}_{2} \stackrel{\mathrm{H}_{2} \mathrm{O}}{\rightarrow} \mathrm{RSO}_{3} \mathrm{H} .
\end{gathered}
$$

\section{Conclusions}

The study showed the total sulfur content in coal processing wastes can be reliably evaluated using the standard LECO combustion method. In terms of methods for analyzing sulfur forms, the ISO157:1996 protocol resulted in a slight underestimation of sulfide sulfur and the overestimation of sulfate sulfur content. However, the differences in the sulfur speciation results obtained with the ISO and the ACARP C15034 protocols were not significant, and both methods can thus be considered sufficiently reliable for analyzing the forms of sulfur.

Whilst speciation results indicated that the majority (52-61\%) of the sulfur is in the form of sulfide sulfur in the samples evaluated, the presence of non-acid forming sulfates and organic sulfur can cause overestimation of acid-generating potential if calculated on the basis of total sulfur. The results of this study have shown, furthermore, that consideration of total sulfur instead of the acid-forming sulfur (such as sulfide and acid-forming soluble sulfates) can result in coals wastes being erroneously classified as acid-generating by means of static chemical tests, especially in cases where samples do not have a high acid generating potential (NAPP $<10$ and NAG $\mathrm{pH}>3$ ).

Another source of inaccuracy in the characterization and classification of ARD potential on the basis of static chemical tests can be attributed to the undesirable reaction of sulfur species under the relatively aggressive test conditions, thus overestimating the acid generating potential. 
In general, the findings of this study highlight the complex sulfur chemistry of coal processing wastes and the associated uncertainties in terms of reliably characterizing and classifying their ARD generating by means of standard chemical static tests. Further validation of the potential ARD generating potential using tests that provide information on the time-related nature of the acid-generating behavior, under conditions which more closely simulate those likely to occur in a disposal scenario, is thus recommended. It is also recommended that mineralogical analysis be used in conjunction with chemical analysis to assist in the interpretation of the results of ARD tests, particularly in terms of understanding the behavior of both the acid-forming and acid-neutralizing minerals.

Author Contributions: Conceptualization, S.T.L.H. and J.L.B.; methodology, A.M., J.R.D.A.F., S.T.L.H. and J.L.B.; formal analysis, A.M., J.R.D.A.F., S.T.L.H. and J.L.B.; investigation, A.M., J.R.D.A.F., S.T.L.H. and J.L.B.; resources, J.R.D.A.F., S.T.L.H. and J.L.B.; writing-original draft preparation, A.M., J.R.D.A.F., S.T.L.H. and J.L.B.; writing-review and editing, A.M., J.R.D.A.F., S.T.L.H. and J.L.B.; supervision, J.R.D.A.F., S.T.L.H. and J.L.B.; project administration, J.L.B.; funding acquisition, S.T.L.H. and J.L.B. All authors have read and agreed to the published version of the manuscript.

Acknowledgments: Financial support for this study was provided by the Water Research Commission of South Africa (project number K5/2580) and the University of Cape Town. The authors wish to acknowledge the contribution of Megan Becker and Gaynor Yorath in the mineralogical analysis.

Conflicts of Interest: The authors declare no conflict of interest.

\section{References}

1. Singer and Stumm. Acidic Mine Drainage-Rate-Determining Step. Science 1970, 167, 1121-1123. [CrossRef] [PubMed]

2. US Environmental Protection Agency. Acid Mine Drainage Prediction, Acid Mine Drainage Prediction; EPA 530-R-94-036; US Environmental Protection Agency: Washington, DC, USA, 1994.

3. Szczepanska, J.; Twardowska, I. Distribution and environmental impact of coal-mining wastes in Upper Silesia, Poland. Environ. Geol. 1999, 38, 249-258. [CrossRef]

4. Hancox, P.J.; Goetz, A.E. South Africa's coalfields-A 2014 perspective. Int. J. Coal Geol. 2014, 132, $170-254$. [CrossRef]

5. Steyn, M.; Minnitt, R.C.A. Thermal coal products in South Africa. J. South. Afr. Inst. Min. Metall. 2010, 110, 593-599.

6. Eberhard, A. The future of South African coal: Market, investment, and policy challenges. Progr. Energy Sustain. Dev. 2011, 1-44. [CrossRef]

7. Prevost, X. A clean future for coal. Insid. Min. 2010, 2010, 14-17.

8. SACRM (South African Coal Road Map). Overview of the South African Coal Value Chain, South African Coal Roadmap; Technical Report; 2011; 299p, Available online: http://www.fossilfule.co.za/initiatives/2013/SACRMValue-Chain-Overview.pdf (accessed on 9 December 2019).

9. Department of Minerals and Energy. National Inventory Discard and Duff Coal-2001 Summary Report. Energy 2001, 2001.

10. Reddick, J.F.; Von Blottnitz, H.; Kothuis, B. A cleaner production assessment of the ultra-fine coal waste generated in South Africa. J. South. Afr. Inst. Min. Metall. 2007, 107, 811-816.

11. Gluskoter, H.J. Inorganic sulfur in coal. IL State Geol. Surv. 1974, 3, 94-98. [CrossRef]

12. European Commision. EUR 17980-Technical Coal Research: Coal Conversion Characterisation of Sulphur in Coal and Coal Products by Standard and Non-Standard Methods; Office for Official Publications of the European Communities: Luxembourg, 1998.

13. Speight, J.G. Handbook of Coal Analysis. In Chemical Analysis A Series of Monographs on Analytical Chemistry and Its Applications; John Wiley \& Sons, Inc.: Hoboken, NJ, USA, 2005; Volume 166.

14. Iroala, O.J. Combining Froth Flotation with Reflux Classification to Mitigate ARD Generating Potential of the Waterberg and Witbank Coal Ultrafines via Sulfide Removal. Ph.D. Thesis, Department of Chemical Engineering, University of Cape Town, Cape Town, South Africa, 2014.

15. Kazadi Mbamba, C.; Harrison, S.T.L.; Franzidis, J.P.; Broadhurst, J.L. Mitigating acid rock drainage risks while recovering low-sulfur coal from ultrafine colliery wastes using froth flotation. Miner. Eng. 2012, 29, 13-21. [CrossRef] 
16. Kotelo, L.O. Characterising the Acid Mine Drainage Potential of Fine Coal Wastes. Ph.D. Thesis, Department of Chemical Engineering, University of Cape Town, Cape Town, South Africa, 2013.

17. Bell, F.G.; Bullock, S.E.T.; Hälbich, T.F.J.; Lindsay, P. Environmental impacts associated with an abandoned mine in the Witbank Coalfield, South Africa. Int. J. Coal Geol. 2001, 45, 195-216. [CrossRef]

18. McCarthy, T.S. The impact of acid mine drainage in South Africa. S. Afr. J. Sci. 2011, 107, 1-7. [CrossRef]

19. Pinetown, K.L.; Ward, C.R.; van der Westhuizen, W.A. Quantitative evaluation of minerals in coal deposits in the Witbank and Highveld Coalfields, and the potential impact on acid mine drainage. Int. J. Coal Geol. 2007, 70, 166-183. [CrossRef]

20. Deysel, L.M.; Vermeulen, D. A Detailed ABA Study of the Coal-Bearing Formations in the Waterberg Coalfield, Limpopo Province, South Africa. In Proceedings of the 10th International Conference on Acid Rock Drainage \& IMWA Annual Conference, Santiago, Chile, 21-24 April 2015; pp. 1-10.

21. Nordstrom and Southam. Geomicrobiology of sulfide mineral oxidation. In Geomicrobiology: Interactions between Microbes and Minerals; Banfield, J.F., Nealson, K.H., Eds.; Mineralogical Society of America: Washington, DC, USA, 1997; Volume 35, pp. 361-390.

22. Lapakko, K. Metal Mine Rock and Waste Characterization Tools: An Overview; The International Institute for Environment and Development (IIED): St. Paul, MN, USA, 2002.

23. Akcil, A.; Koldas, S. Acid Mine Drainage (AMD): Causes, treatment and case studies. J. Clean. Prod. 2006, 14, 1139-1145. [CrossRef]

24. Simate, G.S.; Ndlovu, S. Acid mine drainage: Challenges and opportunities. J. Environ. Chem. Eng. 2014, 2, 1785-1803. [CrossRef]

25. Parbhakar-fox, A.; Lottermoser, B.G. A critical review of acid rock drainage prediction methods and practices. Miner. Eng. 2015, 82, 107-124. [CrossRef]

26. McKibben and Barnes. Oxidation of pyrite in low temperature acidic solutions: Rate laws and surface textures. Geochim. Cosmochim. Acta 1986, 50, 1509-1520. [CrossRef]

27. Lawrence, R.W.; Scheske, M. A method to calculate the neutralization potential of mining wastes. Environ. Geol. 1997, 32, 100-106. [CrossRef]

28. Paktunc, A.D. Mineralogical constraints on the determination of neutralization potential and prediction of acid. Environ. Geol. 1999, 39, 103-112. [CrossRef]

29. Hansford, G.S.; Vargas, T. Chemical and electrochemical basis of bioleaching processes. Hydrometallurgy 2001, 59, 135-145. [CrossRef]

30. Yahya, A.; Johnson, D.B. Bioleaching of pyrite at low $\mathrm{pH}$ and low redox potentials by novel mesophilic Gram-positive bacteria. Hydrometallurgy 2002, 63, 181-188. [CrossRef]

31. Rohwerder, T.; Gehrke, T.; Kinzler, K.; Sand, W. Bioleaching review part A: Progress in bioleaching: Fundamentals and mechanisms of bacterial metal sulfide oxidation. Appl. Microbiol. Biotechnol. 2003, 63, 239-248. [CrossRef] [PubMed]

32. Ahern, C.; McElnea, A.; Sullivan, L. Acid Sulfate Soils Laboratory Methods Guidelines; Department of Natural Resources, Mines and Energy: Indooroopilly, Australia, 2004.

33. Miller, S. ACARP Project C15034: Development of ARD Assessment for Coal Process Wastes; Environmental Geochemistry International Pty Ltd.: Balmain, Australia, 2008.

34. Stewart, W.; Schuman, R.; Miller, S.; Smart, R. Development of Prediction Methods for ARD Assessment of Coal Process Wastes. In Proceedings of the 8th International Conference on Acid Rock Drainage (ICARD), Skelleftea, Sweden, 22-26 June 2009; pp. 1-14.

35. Schumann, R.; Stewart, W.; Miller, S.; Kawashima, N.; Li, J.; Smart, R. Acid-base accounting assessment of mine wastes using the chromium reducible sulfur method. Sci. Total Environ. 2012, 424, 289-296. [CrossRef] [PubMed]

36. Smart, R.; Skinner, B.; Levay, G.; Gerson, A.; Thomas, J.; Sobieraj, H.; Schumann, R.; Weisener, C.; Weber, P. AMIRA International ARD Test Handbook Project P387A Prediction \& Kinetic Control of Acid Mine Drainage; Miller, S., Stewart, W., Eds.; Ian Wark Research Institute: Melbourne, Australia; Geochemistry International Pty: Balmain, Australia, 2002.

37. Descostes, M.; Vitorge, P.; Beaucaire, C. Pyrite dissolution in acidic media. Geochim. Cosmochim. Acta 2004, 68, 4559-4569. [CrossRef]

38. Dold, B. Acid rock drainage prediction: A critical review. J. Geochem. Explor. 2017, 172, 120-132. [CrossRef] 
39. Lawrence, R.W.; Wang, Y. Determination of Neutralization Potential for Acid Rock Drainage Prediction, MEND Project 1.16.3; University of British Columbia: Vancouver, BC, Canada, 1996.

40. Sobek, A.A.; Schuller, W.A.; Freeman, J.R.; Smith, R.M. Field and Laboratory Methods Applicable to Overburdens and Minesoils, Environmental Protection Technology Series; EPA: Cincinnati, OH, USA, 1978.

41. Plante, B.; Bussière, B.; Benzaazoua, M. Static tests response on 5 Canadian hard rock mine tailings with low net acid-generating potentials. J. Geochem. Explor. 2012, 114, 57-69. [CrossRef]

42. Becker, M.; Dyantyi, N.; Broadhurst, J.L.; Harrison, S.T.L.; Franzidis, J.P. A mineralogical approach to evaluating laboratory scale acid rock drainage characterisation tests. Miner. Eng. 2015, 80, 33-36. [CrossRef]

43. Laban, K.L.; Atkin, B.P. The direct determination of the forms of sulphur in coal using microwave digestion and icp-aes analysis. Fuel 2000, 79, 173-180. [CrossRef]

44. Tuttle, M.; Briggs, P.; Berry, C. A Method to Separate Phases of Sulphur in Mine-Waste piles and Natural Alteration Zones, and to Use Sulphur Isotopic Compositions to Investigate Release of Metals and Acidity to the Environment. In Proceedings of the Sixth International Conference on Acid Rock Drainage, Caines, Australia, 14-17 July 2003.

45. Weber, P.A.; Thomas, J.E.; Skinner, W.M.; Smart, R.S.C. Improved acid neutralisation capacity assessment of iron carbonates by titration and theoretical calculation. Appl. Geochem. 2004, 19, 687-694. [CrossRef]

46. Borah, D.; Baruah, M.K.; Haque, I. Oxidation of high sulphur coal. Part 2. Desulphurisation of organic sulphur by hydrogen peroxide in presence of metal ions. Fuel 2001, 80, 1475-1488. [CrossRef]

(C) 2019 by the authors. Licensee MDPI, Basel, Switzerland. This article is an open access article distributed under the terms and conditions of the Creative Commons Attribution (CC BY) license (http://creativecommons.org/licenses/by/4.0/). 